\title{
DISCURSO EDUCATIVO LETRADO DE PROFESSORAS ALFABETIZADORAS DE DIFERENTE PERFIL PEDAGÓGICO
}

Angélica Sepúlveda*

Laboratório de Educação (LABEDU - ONG), São Paulo - SP, Brasil

RESUMO: A presente pesquisa tem por objetivo qualificar o discurso educativo letrado de professoras alfabetizadoras de diferentes perfis pedagógicos durante as atividades de leitura e comentário de um livro de literatura infantil. No estudo, participaram quatro professoras: duas com perfil educativo interativo/construtivo e duas com perfil diretivo/transmissivo. A análise do discurso educativo colocou em evidência que as professoras de perfil interativo/construtivo fizeram significativamente mais referências às atividades de ensino e aprendizagem desenvolvidas em torno do texto, aos processos cognitivos e linguísticos dos alunos em torno da compreensão e da produção de linguagem a partir do texto e à forma e aos conteúdos do próprio texto. Além disso, formularam maior número de perguntas aos alunos, utilizaram com maior frequência diversos verbos de cognição e linguagem e dedicaram mais tempo à realização das atividades.

Palavras-chave: Discurso educativo. Alfabetização. Discurso letrado. Práticas letradas. Perfis pedagógicos.

\section{LITERATE EDUCATIONAL DISCOURSE IN THE LITERACY CLASSROOM: DIFFERENT TEACHING STYLES}

ABSTRACT: This research compares the literate discourse used by four early grade teachers with distinct instructional styles during an in-class reading activity with a children's literature book. Four teachers took part in the study, two of them with an interactive/constructive teaching style and the other two with a directive/transmissive style. The results show that the two teachers who follow an interactive/constructive approach more frequently referenced teaching and learning activities around the text, as well as the students' cognitive and linguistic processes, and the form and content of the text itself. Besides that, these two teachers formulated a greater quantity of questions for students, they have used a variety of cognitive and linguistic verbs, and have devoted more time to developing the proposed activities.

Keywords: Educational discourse. Literacy. Literate discourse. Literate practices. Teaching styles.

http://dx.doi.org/10.1590/0102-4698141263

Elocation-id - e 141263

"Doutora em Psicologia da Educação pela Universidade de Barcelona. Coordenadora de projetos de inovação e pesquisa educativa na organização não governamental Laboratório de Educação. E-mail: $<$ angelica@labedu.org.br $>$. 


\section{INTRODUÇ̃̃o}

Os estudiosos dos efeitos da alfabetização na cognição humana sustentam que o avanço cognitivo resulta da possibilidade de participar em certo tipo de discurso: o discurso letrado ou discurso sobre os textos (HEATH, 1983; OLSON; ASTINGTON, 1990; SCRIBNER; COLE, 1981 citado por OLSON; ASTINGTON, 1990). A partir dessa perspectiva, as práticas alfabetizadoras que beneficiam as crianças são aquelas que lhes oferecem oportunidades para pensar e falar sobre os textos escritos. São as chamadas práticas letradas, aquelas que, desde o início da alfabetização, ajudam os aprendizes a terem acesso à forma como funciona o texto escrito, a aprender sua estrutura, e a conhecer as formas próprias da linguagem que se escreve e suas funções (TEBEROSKY, 2001, 2011).

O discurso que caracteriza esse tipo de práticas alfabetizadoras é reconhecível pela referência às formas e aos significados dos textos e, por isso, aos processos mentais, cognitivos e linguísticos que são necessários para compreender e produzir a linguagem. É próprio da fala sobre textos escritos citar ou parafrasear o escrito para comentá-lo e interpretá-lo, isto é, para pensar no que quer dizer, seu significado e sentido (OLSON, 1994). Essas atividades discursivas requerem o uso de abundante terminologia metacognitiva e metalinguística e, de fato, a quantidade e diversidade de verbos que se referem atividades cognitivas e linguísticas constituem um indicador do caráter letrado do discurso (ASTINGTON; OLSON, 1990; TEBEROSKY; et al., 2006; TORRANCE; OLSON, 1987; WATSON, 1996, 2002).

Alguns dos materiais complementares distribuídos pelo Ministério de Educação para a alfabetização de alunos de seis anos de idade têm a intenção de promover esse tipo de discurso nas salas de aula. Um desses materiais é a coleção Trilhas, para o ensino e aprendizagem inicial de leitura, escrita e oralidade (BRASIL, 2011). Trata-se de um conjunto de materiais e orientações que fomentam ações alfabetizadoras em torno de textos procedentes de obras poéticas e literárias dirigidas à infância. Uma das particularidades do material é que na descrição das atividades sugeridas aos professores são modeladas as formas que podem ser concretizadas nas salas de aula, mediante exemplos das formas em que o professor pode apresentá-las e conduzi-las verbalmente.

Em um estudo prévio (SEPÚLVEDA, 2012), documentamos o uso de um dos exemplares da coleção Trilhas por parte de quatro 
professoras com práticas de alfabetização transmissivas e centradas no ensino da escrita como código. Em todos os casos foram registradas mudanças positivas nos processos de ensino e aprendizagem, especialmente no que diz respeito ao uso do tempo e à participação dos alunos em atividades mais reflexivas acerca dos textos e da escrita. No entanto, observamos diferenças importantes nos modos de fazer as atividades. As professoras que, além de procurarem realizar as atividades, deram atenção às orientações sobre o discurso educativo proposto pelo Trilhas, isto é, aos modos de apresentar e conduzir verbalmente as atividades, ofereceram oportunidades qualitativamente melhores aos seus alunos.

A investigação que apresentamos neste artigo teve a intenção de estudar melhor essa diferença, visando os modos de influir no discurso educativo/letrado como possível meio para potencializar a qualidade das práticas que efetivamente se desenvolvem nas aulas. Partimos da ideia de que a introdução de práticas letradas nas salas de aula exige um trabalho que vai além de "modificar" as atividades e os materiais de ensino, supõe introduzir uma forma nova de pensar (e falar) com as crianças a partir e em torno dos textos. Esse aspecto está estreitamente vinculado aos estilos pedagógicos dos professores - é reconhecido que, aos seus modos de atuar (de ensinar), subjazem concepções sobre os processos de ensino e aprendizagem em geral (BRUNER, 1997), e da leitura e da escrita em particular.

Por essa razão, neste estudo decidimos comparar as respostas de professores com diferentes perfis profissionais (práticas educativas e concepções distintas dos processos de ensino e aprendizagem) aos convites feitos pelo material para o desenvolvimento da atividade de leitura e comentário de um livro de literatura infantil. A diferença, com relação ao estudo anterior, em que somente entregamos o material e registramos o seu uso, diz respeito ao fato de que, nesta pesquisa, optamos por realizar uma intervenção: oferecer indicações para guiar a leitura e o uso. As indicações consistiram em pedir explicitamente às professoras para que atendessem e usassem as orientações relativas ao como apresentar e guiar verbalmente a realização das atividades propostas - discurso educativo letrado. Ou seja, convidamos as professoras para não só fazerem as atividades segundo sua própria compreensão, mas tentarem realizá-las da forma como são propostas nos Cadernos de orientações Trilhas, concretizando esse modo de fazer de acordo com as orientações que modelam o discurso educativo letrado (instruções e comentários verbais, por exemplo). 
Indagamo-nos em que medida professoras de diferentes perfis interativos e pedagógicos se apropriariam dessas orientações e, também, pela qualidade mais ou menos letrada do seu discurso, em função do seu perfil.

\section{PERFIL INTERATIVO DO PROFESSOR E A QUALIDADE DOS EVENTOS LETRADOS}

Há várias décadas, pesquisas de diferentes âmbitos têm nos informado os efeitos da prática da leitura compartilhada de histórias no âmbito do lar ou da escola. Sabemos que as crianças que desde a mais tenra idade têm a possibilidade de ouvir leituras e interagir com leitores desenvolvem uma melhor competência linguística - mais vocabulário receptivo e expressivo, estruturas sintáticas mais elaboradas, compreensão de estruturas narrativas diversas, conhecimentos sobre os diversos usos da linguagem oral e escrita etc.-, apresentam melhor compreensão sobre como funcionam os textos escritos e costumam ter mais sucesso na aprendizagem escolar da leitura e da escrita, e no desempenho acadêmico em geral (BUS; VAN IJZERDOORN; PELLEGRINI, 1995; MORROW, 1997; MORROW; GAMBRELL, 2000; SÉNECHAL, 1997; SÉNECHAL; LEFEVRE, 2002; SNOW; NINIO, 1986; SNOW; BURNS; GRIFFIN, 1998; TEALE; SULZBY, 1986; TEBEROSKY, 1993; WELLS, 1985).

Também as pesquisas educativas sobre a leitura compartilhada de histórias nas aulas de alfabetização documentam numerosos benefícios. Os estudos revelam que os alunos desse tipo de aulas demonstram atitudes favoráveis para com as atividades de leitura e de escrita (MORROW; GAMBRELL, 2000) e um melhor conhecimento das fórmulas de linguagem próprias do escrito (LANCIA, 1997; PAQUETTE, 2007; PAPPAS; VARELAS, 2009; PHILLIPS, 1986; são alunos que conseguem escrever textos mais compridos e complexos (DAHL; FREPPON, 1995; FISHER; HIEBERT, 1990; PRESSLEY et al., 2001), textos que oferecem evidências sobre o desenvolvimento de conhecimento metatextual (DAHL; FREPPON, 1995).

Contudo, nem todas as experiências de leitura compartilhada de histórias são iguais, nem oferecem as mesmas oportunidades de desenvolvimento e aprendizagem às crianças (JOHN, 2009; MARTLEW et al., 2010). Tanto os estudos focados na interação entre pais e filhos quanto aqueles voltados para aula escolar revelam fatores que fazem a diferença. Entre esses fatores, destacam-se a frequência com que as crianças têm a oportunidade de participar em situações 
de leitura de textos (BUS, van IJZERDOORN; PELLEGRINI, 1995); se participam em releituras ou leituras repetidas de textos (MORROW; GAMBRELL, 2000; SÉNÉCHAL, 1997; SNOW, 1983; SNOW; GOLDFIELD, 1983); a qualidade dos textos que ouvem (COLOMER, 2005); a qualidade do vínculo afetivo (BUS; van IJZENDOORN, 1988, 1995); os tipos de interações comunicativas desenvolvidas (SÉNÉCHAL, 1997; WELLS, 1986), entre outros.

São de especial interesse para nossa pesquisa os estudos que destacam a qualidade das interações comunicativas durante as situações de leitura compartilhada de histórias. Esses trabalhos mostram que a qualidade do evento de leitura varia em função do estilo interativo do adulto, da sua sensibilidade às respostas infantis e da forma como ajusta/ usa a linguagem para ajudar a criança a participar do evento letrado (BUS; VAN IJZENDOORN, 1988; BUS; VAN IJZENDOORN; PELLEGRINI, 1995; JOHN, 2009; WELLS, 1986).

O trabalho pioneiro de Gordon Wells (1986) mostrou que os adultos com estilos colaborativos de interação ajudavam as crianças a participar de forma mais efetiva da dinâmica de compreensão das histórias lidas. Em suas observações, adultos com estilos colaborativos costumavam atribuir eficientemente sentido e significado às respostas infantis e lhes ofereciam um maior número de oportunidades para falar e, dessa maneira, uma possibilidade maior de desenvolvimento da linguagem expressiva.

No que diz respeito à responsividade emocional e verbal, as pesquisas de Bus e van IJzendoorn (BUS; VAN IJZENDOORN, 1988; BUS; VAN IJZENDOORN; PELLEGRINI, 1995) sugerem que, quando os pais são menos sensíveis às respostas e necessidades de compreensão das crianças, os eventos de leitura resultam menos gratificantes e prazerosos. Esses autores explicam que essas circunstâncias podem afetar negativamente o desenvolvimento de conhecimentos letrados e o interesse das crianças pela leitura de livros.

$\mathrm{Na}$ mesma linha, estudos de intervenção documentam que as crianças de pais orientados para usar comportamentos comunicativos específicos durante a leitura de livros, como a formulação de perguntas abertas ou o uso de expressões que apreciam com entusiasmo as respostas infantis, aprendem mais vocabulário expressivo que aquelas crianças de pais que não foram instruídos a adotar tal prática (SÉNÉCHAL, 1997; SÉNÉCHAL, CORNELL; BRODA, 1995).

De igual maneira, as pesquisas educativas sobre a leitura compartilhada de histórias em sala de aula convergem ao salientarem que as oportunidades de aprendizagem das crianças variam em 
função do estilo de interação do professor, isto é, da forma como o professor usa a linguagem para ajudar os alunos a aprender. Estudos comparativos e de intervenção sugerem que as interações discursivas em sala de aula que mais beneficiam o desenvolvimento da linguagem e as aprendizagens letradas são aquelas em que o professor estimula as crianças a participarem de forma ativa nos intercâmbios comunicativos em torno dos textos lidos (DOMBEY, 2003; MARTLEW et al. 2010).

\section{DISCURSO EDUCATIVO E APRENDIZAGEM EM SALA DE AULA}

Pesquisas centradas no estudo das relações entre o discurso educativo e os processos de ensino e aprendizagem em sala de aula também ressaltam o papel do estilo interativo dos professores como um fator-chave (MERCER, 2000, 2003; WEGERIF; MERCER; ROJAS-DRUMMOND, 1999).

Os trabalhos de Neil Mercer e colegas (2000) descrevem as características do discurso educativo associado a situações exitosas de ensino e aprendizagem. Em seus estudos observaram que os professores de estudantes com melhores resultados de aprendizagem eram professores que usavam a linguagem para:

- indagar pelo nível de compreensão dos alunos e ajustar o ensino em correspondência;

- além de explicar conteúdos, explicar explicitamente o propósito da organização das atividades que se desenvolvem na aula e como ajudam no processo de aprendizagem;

- fazer séries de perguntas e respostas não somente avaliativas, mas que guiam (ensinam) estratégias de compreensão; e

- estimular raciocínios e reflexões em relação aos conteúdos, mediante perguntas do tipo por que, que ajudam os alunos a aprender a justificar suas respostas, a aprender que o conhecimento é justificável.

Esses usos da linguagem são de especial importância para os alunos, porque lhes permitem, além de representar um conteúdo em particular, ter acesso a seus próprios processos compreensivos, dando, ao mesmo tempo, sentido às situações de aprendizagem em que participam - o que farem em sala de aula, como e porque.

No caso dos processos de ensino e aprendizagem da leitura e da escrita em torno de textos escritos, como é a situação de leitura compartilhada de histórias, esse tipo de usos de linguagem 
resulta significativo porque é esperado que o objeto de muitos dos intercâmbios discursivos em sala de aula se refiram a aspectos próprios dos processos de compreensão e produção de significados.

\section{DISCURSO LETRADO E DISCURSO EDUCATIVO}

O discurso letrado é o discurso oral associado às atividades com textos escritos, em particular, às atividades de leitura, análise e interpretação de textos (OLSON; ASTINGTON, 1990; WATSON, 1989, 1996, 2002). Forma parte das características desses usos da linguagem para falar sobre textos escritos a formulação de perguntas sobre informação conhecida; a solicitude de nomear e descrever; o uso de verbos que se referem a estados cognitivos, emocionais e aos usos da linguagem (TORRANCE; OLSON, 1987; WATSON, 1989, 2002).

Segundo Watson (1989), o uso de verbos metalinguísticos, como significar ou querer dizer, nas típicas perguntas de definição de palavras, de verbos metacognitivos (ou que se referem a estados mentais), como saber, compreender, lembrar e pensar, ou de verbos que se referem a estados afetivos, como querer ou gostar, revelam uma atitude ou postura analítica e interpretativa no discurso próprias dos usos da linguagem para pensar sobre, a partir de e a propósito dos textos escritos. Watson (2002) salienta que essas são as ferramentas necessárias para resolver os problemas que a comunicação escrita cria.

Outros autores têm ressaltado que esse léxico é o que se precisa para fazer definições, para citar ou parafrasear partes do texto, para resumir, descrever, explicar, interpretar, contrastar inferências, colocar em relação um texto com outros textos para fazer pensar e falar/ escrever sobre o escrito (OLSON, 1994; TEBEROSKY et al., 2006; TORRANCE; OLSON, 1987). Por isso, os pesquisadores concordam em salientar que essas características se superpõem com aquelas próprias do discurso educativo (ASTINGTON; OLSON, 1990; WATSON, 1989, 2002). Aliás, que são parte vital do discurso educativo (ASTINGTON; OLSON, 1990) e que aprender esses usos da linguagem (para falar sobre textos escritos) é tão importante quanto a aprendizagem das habilidades de leitura e de escrita (OLSON; ASTINGTON, 1990).

A partir desses referenciais teóricos e empíricos, nesta pesquisa entendemos que a qualidade dos eventos letrados em sala de aula está associada a usos particulares da linguagem durante as interações próprias da atividade de ler e falar sobre textos. No que diz respeito à forma, esses usos da linguagem podem ser descritos como interativos e responsivos, ou seja, têm a intencionalidade de 
construir um verdadeiro diálogo com a criança e, para isso, ajustamse em função e exploram as respostas infantis. No que diz respeito ao conteúdo, incluem a referência aos conteúdos e formas textuais; aos processos cognitivos e linguísticos próprios da compreensão e da produção de linguagem, a partir de textos; e às atividades de ensino e aprendizagem que se desenvolvem em sala de aula, em torno deles. O léxico que caracteriza esses usos da linguagem inclui verbos que se referem a atividades cognitivas (metacognitivos) e linguísticas (metalinguísticas). Sua densidade no discurso sugere uma atitude analítica e interpretativa própria de práticas educativas reflexivas. Essas premissas orientaram, em parte, nossa análise dos dados.

\section{OS MATERIAIS EDUCATIVOS TRILHAS}

A coleção "Trilhas" para o ensino e aprendizagem inicial da leitura, a escrita e a oralidade (BRASIL, 2011) está formada por um conjunto de materiais eorientações que fomentam ações alfabetizadoras em torno de textos procedentes de obras poéticas e literárias dirigidas à infância. Nos diferentes cadernos de orientações são propostos roteiros de atividades com a intenção de promover práticas reflexivas em sala de aula, para ajudar as crianças a compreenderem a escrita e os textos. Desse modo, a coleção mostra sua perspectiva sobre os processos de ensino e aprendizagem e sua opção por práticas de ensino evolutivamente apropriadas (TEBEROSKY, 2001, 2011).

Trilhas é formado por três grandes conjuntos de materiais: um centrado em jogos da linguagem, outro em textos poéticos e outro em livros narrativos. Nesta pesquisa usamos um dos exemplares desse último conjunto de materiais. Trata-se do Caderno de orientações: histórias com engano. Esse caderno explica a categoria histórias com engano, e justifica sua importância; descreve uma série de livros de literatura infantil que são exemplos de histórias com engano e apresenta oito atividades que podem ser realizadas a partir desse tipo de livro.

Como explicamos no início deste artigo, esses materiais resultam especialmente apropriados para a pesquisa que realizamos, porque, além de propor materiais e atividades a serem usados em sala de aula, oferecem exemplos do discurso educativo que pode acompanhar o uso de tais materiais e o desenvolvimento das atividades.

Da nossa perspectiva, a análise dos exemplos contidos nos roteiros de trabalho do Caderno de orientações mostra que há indicações relativas a como falar com as crianças sobre: 
a) As atividades de ensino e aprendizagem que se realizam sobre o texto. São enunciados típicos desse tipo de orientações: hoje vamos ler...; vamos recordar a história...; vou perguntar para vocês...; vou ler e depois conversamos...

b) Os processos de aprendizagem ativados para pensar em torno, sobre e a partir dos textos lidos. Os enunciados típicos desse tipo de orientações propõem ao professor indagar pelos pensamentos e crenças das crianças em relação a diversos conteúdos do texto, da linguagem e da escrita. Alguns exemplos são:

1. Olhando a capa do livro, qual vocês imaginam que é o título dessa história? Nesse caso, a indagação do professor se refere a um conteúdo cognitivo, pede uma suposição dos alunos, em relação ao título do texto.

2. Que bichos serão esses que estão na capa? O que será que fazem na história? Com o objetivo de ativar processos antecipatórios e a formulação de hipóteses e conjecturas sobre o texto, é orientado ao professor ajudar os alunos a explicitarem suas crenças, o que estão pensando a propósito do índice do livro ou da história até então desconhecidos. É importante destacar que, geralmente, esse tipo de enunciado se constrói em torno de um verbo ou ação cognitiva, isto é, explicita para a criança o processo cognitivo focado: imaginar, lembrar, observar, achar etc.

c) O texto. São enunciados que orientam o professor a fazer comentários ou indagar diretamente pelos conteúdos ou formas textuais. Alguns exemplos desse tipo de enunciados são:

1. Este livro conta a história de uma família de cabritos. Certo dia, a mãe dos cabritinhos, a Cabra, precisou sair para fazer compras e alertou os cabritinhos que não abrissem a porta para ninguém.

2. Onde se passa essa história? De quem fala essa história? Quem mais está presente nela? O que acontece quando a Cabra sai de casa e deixa os cabritinhos?

No Quadro 1, quantificamos e descrevemos os enunciados propostos nas primeiras três atividades do Caderno de orientacõos: histórias com engano. Na primeira atividade, de caráter introdutório à leitura do livro Os sete cabritinhos (BALLESTEROS; RODRÍGUEZ; MÍGUEZ, 2009), predominam orientações que estimulam o professor a ativar pensamentos antecipatórios, por parte das crianças, em torno da história. Assim, ele é convidado a perguntar pelas crenças e conjecturas dos seus alunos. Na segunda atividade, que foca os elementos da estrutura da narração, predominam as indicações e exemplos sobre como indagar e 
comentar esses aspectos explicitamente. Por conseguinte, predominam orientações de fala sobre os textos. Finalmente, na atividade três, que foca a compreensão das intenções das personagens, também predominam as orientações de fala sobre os textos.

QUADRO 1 - Categorização do conteúdo das orientações para o professor dos roteiros de trabalho das primeiras três atividades do Caderno de orientações: histórias com engano

\begin{tabular}{|c|c|c|c|c|c|c|}
\hline \multirow[t]{2}{*}{$\begin{array}{l}\text { Tipo de } \\
\text { enunciado }\end{array}$} & \multicolumn{2}{|l|}{$\begin{array}{l}\text { ATIVIDADE } 1 . \\
\text { Ler a história e conversar } \\
\text { sobre ela }\end{array}$} & \multicolumn{2}{|l|}{$\begin{array}{l}\text { ATIVIDADE } 2 . \\
\text { Conversar sobre a } \\
\text { estrutura narrativa }\end{array}$} & \multicolumn{2}{|c|}{$\begin{array}{c}\text { ATIVIDADE } 3 \text {. } \\
\text { Conversar sobre o que pensam } \\
\text { e falam os personagens }\end{array}$} \\
\hline & Exemplos & $\mathrm{N}$ & Exemplos & $\mathrm{N}$ & Exemplos & $\mathrm{N}$ \\
\hline $\begin{array}{l}\text { Fala sobre } \\
\text { as atividades } \\
\text { de ensino }\end{array}$ & $\begin{array}{l}\text { Vamos conhecer... } \\
\text { Vou ler para vocês... } \\
\text { Vamos ler para } \\
\text { descobrir o final... }\end{array}$ & 4 & $\begin{array}{l}\text { Vamos recordá-la e } \\
\text { conversar sobre ela. }\end{array}$ & 2 & $\begin{array}{l}\text { Vou ler a história de novo } \\
\text { e vocês vão tentar perceber } \\
\text { quando o Lobo tenta } \\
\text { enganar os cabritinhos. }\end{array}$ & 1 \\
\hline $\begin{array}{l}\text { Fala sobre } \\
\text { os processos } \\
\text { psicológicos } \\
\text { das crianças }\end{array}$ & $\begin{array}{l}\text { Qual vocês imaginam que } \\
\text { é o título desta história? } \\
\text { Será que o Lobo vai conseguir } \\
\text { enganar os cabritinhos? } \\
\text { Conhecem histórias em que } \\
\text { os personagens tentam } \\
\text { enganar os outros? }\end{array}$ & 8 & $\begin{array}{l}\text { Vocês lembram } \\
\text { desta história? }\end{array}$ & 2 & $\begin{array}{l}\text { Vocês lembram que nesta } \\
\text { história o Lobo tenta } \\
\text { enganar os cabritinhos? }\end{array}$ & 2 \\
\hline $\begin{array}{l}\text { Fala sobre } \\
0 \text { texto }\end{array}$ & $\begin{array}{l}\text { Este livro conta a história de } \\
\text { uma família de cabritos... }\end{array}$ & 1 & $\begin{array}{l}\text { O que aconteceu quando } \\
\text { a Cabra sai de casa e } \\
\text { deixa os cabritinhos? } \\
\text { O que o Lobo diz para } \\
\text { os cabritinhos? }\end{array}$ & 8 & $\begin{array}{l}\text { Por que o Lobo disse } \\
\text { isso aos cabritinhos? Era } \\
\text { verdade? O que o Lobo } \\
\text { queria realmente? }\end{array}$ & 0 \\
\hline
\end{tabular}

Fonte: Elaboração própria.

A referência de todos os enunciados propostos sempre é o texto, ainda que varie o foco: na atividade conjunta de ensino aprendizagem ou na atividade psicológica ou cognitiva dos alunos ou foco nas características do próprio texto (de conteúdo ou formais). A Figura 1 oferece uma representação desse primeiro sistema de categorias.

FIGURA 1 - Referência ao texto do discurso educativo letrado

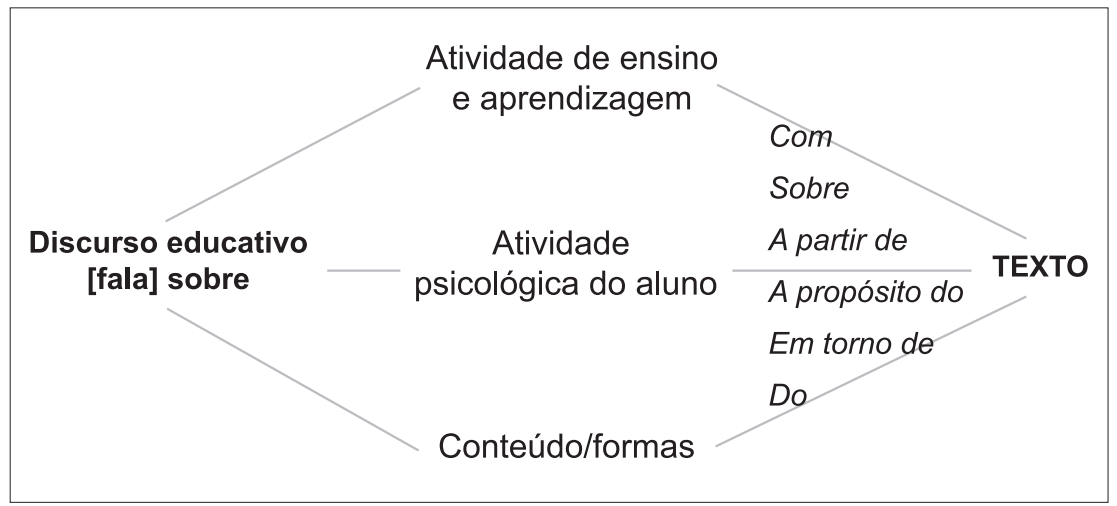

Fonte: Elaboração própria. 
Neste estudo, nos propusemos a comparar a compreensão e o uso por parte de professoras com diferentes perfis pedagógicos desse tipo de discurso educativo letrado.

\section{METODOLOGIA}

A metodologia do presente estudo consistiu na descrição e comparação de múltiplos casos, professoras alfabetizadoras com diferentes estilos de ensino e interação com os alunos.

\section{Participantes}

Participaram quatro professoras do primeiro ano do Ensino Fundamental pertencentes às equipes docentes de duas escolas públicas, uma localizada no estado de São Paulo e a outra no estado de Mato Grosso, nas cidades de São Paulo e Juína respectivamente. São escolas que tinham recebido a coleção Trilhas, mas que ainda não a tinham usado.

Em cada escola identificamos professoras com perfis profissionais distintos. Para estabelecê-los elaboramos um instrumento ad hoc (ver Anexo A) para caracterizar as práticas alfabetizadoras, a partir da observação direta das atividades típicas de ensino e aprendizagem realizadas em sala de aula; em particular, uma sessão de leitura de um livro de literatura infantil escolhido livremente por cada professora. Assim, em cada escola encontramos uma professora que respondia ao perfil diretivo/transmissivo, com práticas centradas no ensino da escrita como código, e outra que respondia ao perfil interativo/construtivo, com práticas equilibradas que focavam aspectos da aprendizagem da escrita da linguagem como da linguagem que se escreve. No Quadro 2 , oferecemos informações adicionais sobre as participantes.

QUADRO 2 - Dados descritivos das professoras participantes

\begin{tabular}{|c|c|c|c|c|}
\hline & MT-D & MT-I & SP-D & SP-I \\
\hline Idade & 43 & 36 & 48 & 49 \\
\hline $\begin{array}{l}\text { Anos de experiência } \\
\text { em alfabetização } \\
\text { inicial }\end{array}$ & 3 & 3 & 4 & 10 \\
\hline Formação acadêmica & Pedagogia & $\begin{array}{l}\text { Educação Infantil } \\
\text { e Séries Iniciais }\end{array}$ & Pedagogia & Pedagogia \\
\hline Formação continuada & $\begin{array}{l}\text { Alfabeletrar } \\
\text { PNAIC (em curso) }\end{array}$ & $\begin{array}{l}\text { Alfabeletrar } \\
\text { PNAIC (em curso) }\end{array}$ & $\begin{array}{l}\text { PIC } \\
\text { TOF } \\
\text { PNAIC (em curso) }\end{array}$ & $\begin{array}{l}\text { PIC } \\
\text { TOF } \\
\text { PNAIC (em curso) }\end{array}$ \\
\hline
\end{tabular}

Nota: as abreviações referem-se ao estado e perfil das participantes: MT-D (Mato Grosso perfil diretivo/transmissivo); MT-I (Mato Grosso perfil interativo/construtivo); SP-D (São Paulo perfil diretivo/transmissivo) e SP.I (São Paulo perfil interativo/construtivo).

Fonte: Elaboração própria. 


\section{Procedimento}

Realizaram-se dois encontros prévios ao levantamento de dados em sala de aula, com uma duração de aproximadamente $1 \mathrm{~h} 30 \mathrm{~min}$ cada um. Nesses encontros, a equipe de pesquisa apresentou os materiais da coleção Trilhas selecionados para a experiência e ofereceu conselhos para a sua compreensão e o seu uso. Os materiais entregues foram: a) O Caderno de orientações: histórias com engano; b) O livro de literatura infantil Os sete cabritinhos (BALLESTEROS; RODRÍGUEZ; MÍGUEZ, 2009); e c) O Caderno de estudos Trilhas par ler e escrever textos. As professoras tiveram um prazo variável para ler e planejar suas aulas, de acordo com as possibilidades das escolas. Na cidade de São Paulo (SP), as professoras contaram com quinze dias para realizar a leitura e planejar suas aulas e, na cidade de Juína (MT), com trinta dias.

$\mathrm{Nas}$ duas reuniões a equipe de pesquisa explicitou a cada participante o interesse particular do estudo em relação às sugestões e orientações que o material oferece sobre como apresentar e guiar verbalmente a realização das atividades. Desse modo, pedimos que elas lessem com atenção os modelos/exemplos relativos às formas de dizer presentes no Caderno de orientações (ver exemplo no Anexo B) e na segunda reunião novamente as professoras foram convidadas a tentar construir conversas educativas na sala de aula, tal qual se propõe nos roteiros de trabalho do Caderno de orientações. Feito isso, agendamos os dias para registrar a realização das atividades.

\section{Dados e análises}

Para este estudo analisamos os dados procedentes da gravação em vídeo das atividades realizadas, seguindo o Caderno de orientações: histórias com engano. Especificamente, o discurso das professoras no desenvolvimento da Atividade 1: "ler a história e conversar sobre ela" (ver Anexo B). Selecionamos para análise o discurso relacionado com a atividade de aprendizagem e não o relativo à organização e controle social dos alunos. Identificamos em cada turno de palavra da professora os enunciados emitidos, levando em conta para a decisão os contextos linguísticos antecedente e consequente. Nesse processo usamos o programa de análise de dados Atlas/ti, versão 5.5 (ATLAS.TI SCIENTIFIC SOFTWARE DEVELOPMENT GMBH, 2002/2011), especificamente a ferramenta quotation count para contabilizar o número de enunciados codificados por categoria.

A primeira análise consistiu em verificar a apropriação e o uso das orientações expostas no material educativo. Para isso, 
elaboramos um inventário de ações que reproduz as instruções dadas às professoras para o desenvolvimento da Atividade 1. "Ler a história e conversar sobre ela", expostas no roteiro de trabalho do Caderno de orientações utilizado na pesquisa.

As análises seguintes foram realizadas a partir das medidas usadas no nosso estudo anterior (SEPÚLVEDA, 2012) e tendo em conta os referenciais teóricos e empíricos da pesquisa, assim, optamos pelas descrição e análise a seguir:

- os segmentos de atividade e o uso do tempo;

- o conteúdo e a função dos enunciados empregados pela professora, durante a apresentação e a realização das atividades, que nomeamos como "categorização do discurso educativo letrado";

- os verbos metacognitivos e metalinguísticos presentes no discurso da professora.

Em geral, a análise serviu tanto para caracterizar a prática de cada uma das professoras, seguindo as orientações de Trilhas, quanto para realizar comparações entre elas. A seguir, definimos e explicamos cada uma das análises citadas.

\section{Os segmentos de atividade e o uso do tempo}

A partir da proposta de Coll e colaboradores (1995) de análise das formas de organização da atividade entre professores e alunos, foram identificados os diferentes conjuntos de ações que caracterizaram a atividade realizada e foi medido o tempo dedicado a cada um deles. Essa análise permitiu-nos visualizar a macroorganização da atividade e seu progresso na dimensão temporal, aspectos especialmente úteis na realização de comparações e na interpretação dos dados.

\section{Discurso educativo letrado}

O sistema geral de análise do conteúdo do discurso educativo letrado resultou de vários processos de codificação tanto dedutivos quanto indutivos, ou seja, no uso de sistemas de categorias predeterminados, emergiram dos dados novas categorias e subcategorias que configuraram o sistema de codificação finalmente utilizado (ver Figura 2). As categorias predeterminadas foram as relacionadas com o conteúdo dos enunciados (sobre o que fala). Segundo nossos referenciais teóricos, esperamos identificar 1) enunciados 
sobre as atividades de ensino e aprendizagem a serem realizadas (que foram ou estão sendo realizadas) com o texto; 2) enunciados sobre os processos psicológicos das crianças realizados sobre, com e a partir do texto e 3) enunciados sobre o texto em si mesmo.

As definições operativas das categorias utilizadas para a codificação do discurso educativo letrado foram:

a) Fala sobre as atividades de ensino e aprendizagem (foco na atividade conjunta). Enunciados que se referem às ações realizadas pelo professor e pelos alunos em torno de, a partir de ou sobre o texto. Foram codificados nessa categoria enunciados como: hoje vamos ler...; vamos recordar a história...; vou perguntar para vocês...; eu vou ler e depois conversamos...

b) Fala sobre os processos psicológicos dos alunos (foco na atividade do aluno). Enunciados nos quais o professor se refere explicitamente às ações de aprendizagem (cognitivas ou linguísticas) dos alunos em torno, sobre e a partir dos textos lidos. Foram codificados nessa categoria enunciados, perguntas e afirmações sobre crenças, conhecimentos e emoções dos alunos em relação ao texto. Alguns exemplos são: o que vocês imaginam?; $O$ que acharam que vai acontecer?; Gostaram da história?; Raul lembron o que disse o Lobo... Também se codificaram nessa categoria os enunciados nos quais a professora repete ou cita as respostas e palavras ditas pelos alunos.

c) Fala sobre o texto (foco no próprio texto). Enunciados que se referem aos aspectos do próprio texto tanto no que diz respeito ao conteúdo do texto quanto à sua forma (a sua textualidade, incluindo seu caráter intertextual). Foram codificados nessa categoria enunciados como: 0 nome da história é Os sete cabritinhos...; Este livro conta a história de uma família de cabritos...; Onde se passa essa história?... O que aconteceu quando a Cabra saiu de casa e deixon os cabritinhos?; Quais são as personagens da bistória?

Uma vez estabelecido e aplicado esse primeiro sistema de categorias, realizamos sucessivos processos de codificação dos diferentes subconjuntos de dados que íamos obtendo. Assim, no caso do conjunto de enunciados categorizados como fala sobre os processos psicológicos dos alunos, contabilizamos duas distinções, uma referente ao modo predominante do enunciado e outra ao seu conteúdo. Em relação ao modo, observamos que, quando uma professora focava os processos psicológicos dos alunos, o fazia por meio de perguntas ou de afirmações que podiam ter relação com três tipos de conteúdos psicológicos: crenças, conhecimentos ou emoções. A definição dessas categorias e subcategorias utilizadas para codificar a fala sobre os processos psicológicos dos alunos foram: 
a) Segundo o modo do enunciado:

1. Perguntas: enunciados nos quais o professor se refere às ações psicológicas dos alunos, em torno, sobre e a partir dos textos lidos por meio da formulação de perguntas. Por exemplo: vocês lembram o que disse a mãe dos cabritinhos?

2. Afirmações: enunciados nos quais o professor se refere às ações psicológicas dos alunos, em torno, sobre e a partir dos textos lidos por meio de expressões declarativas ou afirmativas. Por exemplo: agora vocês sabem o que aconteceu na história...

b) Segundo o conteúdo dos enunciados:

1. Sobre crenças: são enunciados nos quais o professor indaga e/ou se refere às suposições dos alunos em torno do texto. Por exemplo: o que vocês acham que vai acontecer?; Vocês pensavam que o lobo ia conseguir enganar desta vez?

2. Sobre conhecimentos: são enunciados nos quais o professor indaga os e/ou se refere aos conhecimentos dos alunos sobre e/ou em torno do texto. Por exemplo: você se lembra da história onde uma bruxa engana?; Ana disse que Branca de Neve também é uma história em que uma personagem engana.

3. Sobre emoç̃es: são enunciados nos quais o professor indaga e/ou se refere às respostas emotivas dos alunos ao texto. Por exemplo: vocês gostaram da história?; João gostou mais da parte da farinha...

No caso dos enunciados categorizados como fala sobre textos, debruçamo-nos sobre as distinções encontradas no nosso primeiro estudo (SEPÚLVEDA, 2012). Nesse estudo perguntamos o que faziam as professoras quando falavam sobre os textos, o que achamos foi que faziam paráfrases do texto e diferentes tipos de comentários. As definições operativas dessas categorias para codificar a fala sobre textos foram:

a) Paráfrase do texto. Os enunciados do professor (perguntas ou afirmações) são formulados com a intencionalidade de repetir ou recontar, parafraseando o texto lido. Em geral, estão presentes durante a leitura do texto.

b) Comentários referenciais. Os enunciados do professor são produzidos para indicar aspectos observáveis no livro, em geral, para denominar aspectos das ilustrações. É característico desses enunciados o uso de palavras demonstrativas como esse, aquela ou de advérbios de lugar como aqui, ali. 
c) Comentários interpretativos. Enunciados do professor que expressam compreensões ou deduções feitas sobre o texto lido. A finalidade desses comentários é transmitir a interpretação (do professor) do texto e não estimular o trabalho interpretativo por parte das crianças.

d) Comentários metatextuais. Enunciados que comentam aspectos do conteúdo ou a forma do texto (da sua textualidade e caráter intertextual). Assim, foram codificadas nessa categoria perguntas ou afirmações do professor relacionadas com as personagens da história, as causas e consequências dos eventos, o início e o fim, e também comentários relativos aos diálogos, ao vocabulário, ao nome da história, seu autor, a semelhança do texto com outros textos etc.

A abundante presença de enunciados categorizados como comentários metatextuais levou a uma classificação exaustiva segundo o seu conteúdo. A Figura 2 oferece um panorama resumido do sistema de categorias e subcategorias finalmente configurado nesta análise do discurso educativo letrado.

Para avaliar a fiabilidade do sistema de análise proposto, os códigos definidos para o estudo do discurso educativo letrado (fala sobre as atividades de ensino e aprendizagem, fala sobre os processos psicológicos dos alunos, e fala sobre texto) e para o subconjunto de dados Fala sobre textos foram aplicados por dois observadores independentemente. Para a primeira categorização do discurso educativo letrado, o grau de acordo obtido oscilou entre $82 \%$ e $93 \%$. Para a categorização sobre os atos discursivos realizados na fala sobre textos o grau de acordo entre os observadores oscilou entre $81 \%$ e $91 \%$.

$\mathrm{Na}$ primeira categorização, a principal dificuldade de acordo entre os observadores esteve na diferenciação dos enunciados sobre a atividade psicológica do aluno sobre o texto daqueles enunciados sobre o texto mesmo. Ainda que nos primeiros geralmente haja presença de um verbo que explicita a atividade psicológica (vocês lembram...; Raul imaginou que...; vocês conhecem...; vocês olharam...), há enunciados nos quais esse verbo está elidido e tem que ser inferido, como no caso das perguntas antecipatórias do tipo será que o lobo vai conseguir?...; vocês acham que os cabritinhos vão abrir?. Os enunciados categorizados como fala sobre textos foram aqueles nos quais a professora se refere a aspectos da estrutura ou conteúdo do texto sem se referir à atividade psicológica dos alunos (o lobo é uma das personagens da história...; E o que aconteceu depois?...; O lobo queria enganar os cabritinhos...).

Também levaram a desacordo os enunciados em que a professora repete as respostas dos alunos, às vezes citando-as, 
parafraseando-as ou expandindo-as. No caso de sequências em que a professora estava indagando pelos conhecimentos ou crenças dos alunos, essas repetições das palavras dos alunos foram categorizadas como fala sobre os processos psicológicos das crianças, pois o foco está no que disse (sabe, pensa) o aluno. Mas quando a professora repete as palavras dos alunos, em uma sequência de comentário dos acontecimentos da história (ou de qualquer outro aspecto do conteúdo ou da estrutura do texto), os enunciados foram categorizados como fala sobre textos, porque o conteúdo dominante do enunciado era o texto mesmo e não a atividade do aluno sobre o texto.

O processo de análise interobservadores também nos permitiu formular duas advertências que devem ser tidas em conta na réplica do sistema de categorias. A primeira diz respeito a que todos os enunciados selecionados para a análise são aqueles que fazem referência ao texto (nesse sentido o discurso letrado). O sistema de categorias aqui proposto estabelece diferenças nos conteúdos desses enunciados, explorando o seu foco. A segunda advertência diz respeito a não esquecer que o sistema de categorias está baseado no conteúdo dos enunciados e não sobre os processos compreensivos subjacentes. Nesse sentido, nosso trabalho não analisa o trabalho pedagógico de "compreensão da leitura", ainda que possa dialogar com trabalhos empíricos que analisam as conversas sobre textos com a intenção de caracterizar como se ensina a compreensão (BRANDÃO; LEAL; NASCIMENTO, 2013). Nosso trabalho caracteriza, desde outro ponto de vista, o letrado, o discurso educativo sobre os textos.

\section{Verbos metacognitivos e metalinguísticos}

Esta análise mede a quantidade e o tipo de verbos sobre ações mentais e linguísticas presentes no discurso das professoras. Trata-se de uma medida usada em estudos relativos à fala sobre textos (ASTINGTON; OLSON, 1990; TORRANCE; OLSON, 1987; WATSON, 1996) e sobre o discurso letrado na sala de aula (Teberosky et al., 2006). 
FIGURA 2 - Conjunto de categorias e subcategorias estabelecidas para análise do discurso educativo letrado

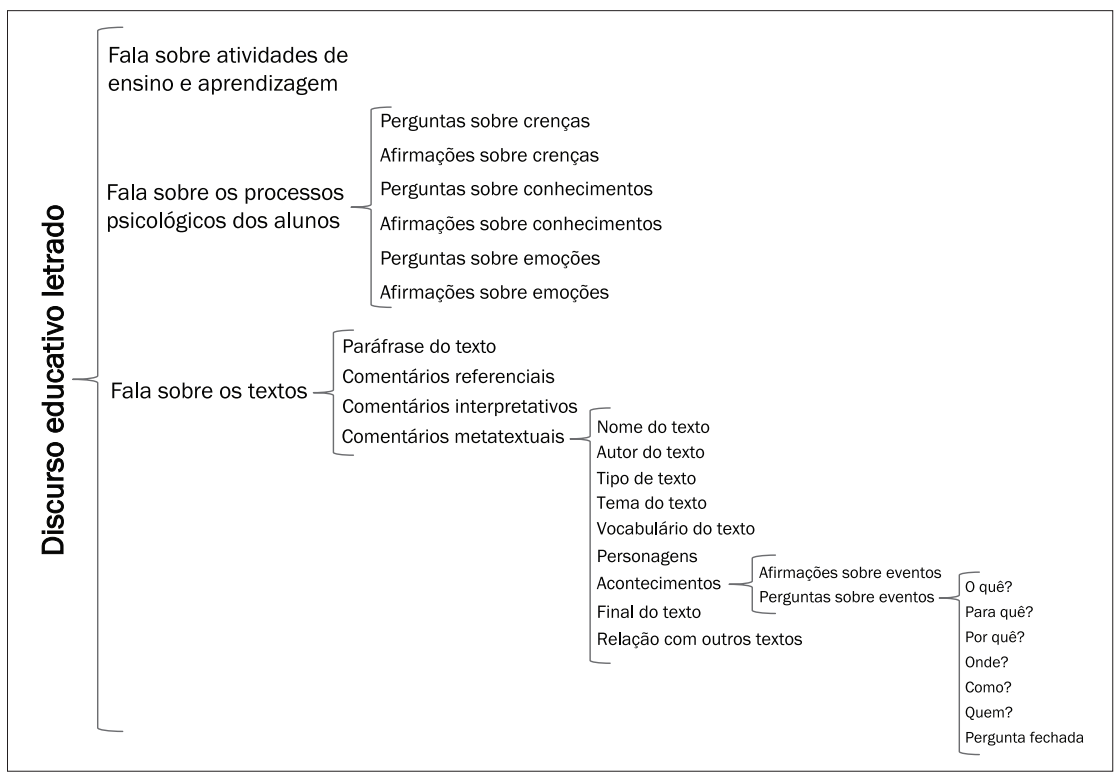

Fonte: Elaboração própria.

\section{RESULTADOS}

\section{Apropriação do discurso educativo letrado modelado nos materiais educativos}

Conferimos o acompanhamento das orientações oferecidas no roteiro de trabalho para a primeira atividade do Caderno de orientações: histórias com engano (ver Quadro 3). Comparando o acompanhamento do roteiro por estado, observamos que, em Mato Grosso, a professora de perfil interativo/construtivo (MT-I) conseguiu acompanhar um maior número das ações propostas e, ainda assim, usar algumas (ainda que poucas) das instruções verbais exemplificadas, enquanto a professora de perfil diretivo/ transmissivo não usou nenhuma. As professoras de São Paulo acompanharam mais fielmente o roteiro de trabalho proposto, sendo muito mais literal a abordagem da professora de perfil diretivo/transmissivo do que a de perfil interativo/construtivo.

\section{Segmentos de atividade e uso do tempo}

Os dados relativos à identificação dos segmentos de atividade e ao uso do tempo mostram importantes diferenças e semelhanças entre os perfis e as professoras. Tanto no caso das professoras do 
Mato Grosso quanto no caso das professoras de São Paulo, o perfil interativo/construtivo dedicou o dobro do tempo para realizar as mesmas atividades. Na Tabela 1 observamos que as professoras de perfil diretivo/transmissivo coincidiram no tipo de leitura em voz alta realizada, uma leitura contínua, sem estimulação da participação das crianças; enquanto as professoras de perfil interativo/construtivo realizaram leituras compartilhadas e reconstruíram a história, depois de lida, por meio de numerosas questões.

As ações mais distantes foram as das professoras do Mato Grosso no segmento anterior à leitura. A professora de perfil diretivo/transmissivo (MT-D) apresentou o livro, mostrando a capa e focando o trabalho de estimular antecipações em torno da seguinte questão: A história se chama: "Os sete cabritinhos", mas nós vamos descobrir por que aqui na capa tem oito cabritinhos - questão pouco afortunada que não conseguiu cumprir a função de pergunta-guia procurada pela professora. Ao mostrar as ilustrações do livro para as crianças, ela não fez comentários ou levantou questões e passou diretamente à leitura em voz alta. Diferentemente, a professora de perfil interativo/ construtivo (MT-I) realizou, antes da leitura, uma extensa atividade de conjectura e formulação de antecipações, a partir da visualização das ilustrações de cada uma das páginas duplas do livro.

QUADRO 3 - Ações do roteiro de trabalho realizadas pelas professoras na atividade de leitura do texto

\section{ATIVIDADE 1. LER A HISTÓRIA E CONVERSAR SOBRE ELA MT-D MT-I SP-D SP-I}

- Organização do espaço e das crianças. Organizar as crianças de forma que fiquem confortáveis para ouvir uma nova história.

X $\quad X$

- Mostrar o livro e dizer que conhecerão uma nova história e depois conversarão sobre ela.

$X \quad X \quad X$

Hoje vamos conhecer uma nova história.. $x \quad x$

Vou ler para vocês e depois conversamos um pouco sobre ela... $x \quad x$

0 que será que ela nos mostra?

- Apresentar a capa do livro, ler os nomes do autor e do ilustrador e fazer perguntas sobre o nome do bicho escrito no título.

$x$ $X \quad X$

Olhando a capa do livro, qual vocês imaginam que é o título dessa história?

Que bichos serão esses que estão na capa? 0 que será que fazem na história?

Relacionar informações sobre o título e as ilustrações do livro, e antecipar os acontecimentos da narrativa.

X $x$

$X \quad x$

$x \quad x$

$X \quad X \quad X$ 
QUADRO 3 - Ações do roteiro de trabalho realizadas pelas professoras na atividade de leitura do texto (continuação).

\section{ATIVIDADE 1. LER A HISTÓRIA E CONVERSAR SOBRE ELA MT-D MT-I SP-D SP-I}

- $\quad$ Folhear as ilustrações do livro.

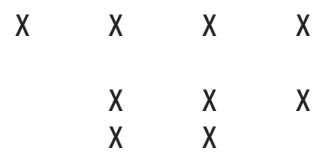

as crianças a observar quem são os personagens

e 0 que fazem ao longo da narrativa. Ao mostrar a

primeira página, em que aparece 0 Lobo, perguntar:

$\begin{array}{lllll}\text { Quem será que é essa personagem? } & & X & X \\ 0 \text { que será que ele quer fazer? } & X & X & X\end{array}$

- Apresentar a história, deixando no ar, como um suspense, 0 seu desfecho:

Este livro conta a história de uma família de cabritos.

Certo dia, a mãe dos cabritinhos, a Cabra, precisou sair

para fazer compras e alertou os cabritinhos que não

abrissem a porta para ninguém. Porém, ao ver a Cabra

saindo, o Lobo rapidamente tentou enganar os cabritinhos

para entrar na casa deles e comê-los.

Será que o Lobo vai conseguir enganar os cabritinhos?

Vamos ler para descobrir o final.

- Ler 0 livro novamente até a página em que 0 Lobo aparece pela primeira vez. Parar e retomar a pergunta que fez às crianças antes de ler. Lançar outras perguntas como:

Mas como vocês acham que os cabritinhos vão escapar?

Dizer que irá terminar de ler para descobrir 0 que acontece.

- Relacionar informações sobre a história e pensar sobre seu desfecho.

- Terminar de ler e chamar a atenção para as partes da história em que 0 Lobo tenta enganar os cabritinhos.

Perguntar se as crianças conhecem histórias em que os personagens tentam enganar os outros. Você pode fazer uma lista de "histórias de engano" como, por exemplo, Chapeuzinho vermelho, Branca de neve, Gato de botas.

- Lembrar histórias com situações de engano.

Fonte: Elaboração própria. 
TABELA 1 - Identificação dos segmentos de atividade e uso do tempo

\begin{tabular}{|c|c|c|c|c|}
\hline \multirow{2}{*}{ Segmentos da atividade } & \multicolumn{4}{|c|}{ Tempo dedicado } \\
\hline & MT-D & MT-I & SP-D & SP-I \\
\hline \multicolumn{5}{|l|}{ Antes da leitura } \\
\hline Apresentação do livro & $4^{\prime}$ & $5^{\prime}$ & $2^{\prime}$ & $3^{\prime}$ \\
\hline Visualização das ilustrações do livro & $6^{\prime}$ & & & \\
\hline $\begin{array}{l}\text { Visualização das ilustrações do livro e estimulação } \\
\text { da formulação de conjecturas sobre a história }\end{array}$ & & $35^{\prime}$ & $4^{\prime}$ & $3^{\prime}$ \\
\hline \multicolumn{5}{|l|}{ Durante a leitura } \\
\hline Leitura em voz alta (contínua) & $10^{\prime}$ & & $8^{\prime}$ & \\
\hline Leitura em voz alta (compartilhada) & & $20^{\prime}$ & & $19^{\prime}$ \\
\hline \multicolumn{5}{|l|}{ Depois da leitura } \\
\hline Conversa sobre a história & $6^{\prime}$ & $20^{\prime}$ & $6^{\prime}$ & $15^{\prime}$ \\
\hline Total de tempo em minutos & $26^{\prime}$ & 70' & 20' & 40' \\
\hline
\end{tabular}

Fonte: Elaboração própria.

\section{O discurso educativo letrado na realização da atividade}

A categorização do discurso educativo das professoras em torno do texto lido revelou importantes diferenças entre os perfis (ver Tabela 2). No caso das professoras do Mato Grosso, a diferença de abordagem entre os perfis foi mais acentuada. A professora de perfil interativo/ construtivo (MT-I) fez dez vezes mais referências à atividade conjunta (de ensino-aprendizagem) com o texto, sete vezes mais referências aos processos psicológicos das crianças em relação ao texto e triplicou o dado das referências ao texto em si mesmo, se comparada à professora de perfil diretivo/transmissivo (MT-D). De forma semelhante, mas com uma distância menor, a professora do perfil interativo/construtivo de São Paulo triplicou as referências em relação à atividade conjunta e aos processos psicológicos das crianças e quadruplicou o dado relativo às referências ao próprio texto, se comparada à professora de perfil diretivo/transmissivo (SP-D). Esses resultados oferecem evidências precisas do modo como as concepções sobre o ensino e a aprendizagem, em geral, e da leitura e escrita, em particular, manifestam-se nas formas de realizar "práticas letradas" nas salas de aula. 
TABELA 2 - Categorização do discurso educativo letrado: número de enunciados por categoria

\begin{tabular}{lcccc}
\hline \multirow{2}{*}{ Categorias de análise } & \multicolumn{4}{c}{ Número total de enunciados por código } \\
\cline { 2 - 5 } & MT-D & MT-I & SP-D & SP-I \\
\hline Fala sobre atividades de ensino-aprendizagem & 2 & 24 & 7 & 21 \\
Fala sobre processos psicológicos dos alunos & 6 & 43 & 23 & 61 \\
Fala sobre textos & 22 & 66 & 18 & 98 \\
\hline
\end{tabular}

Fonte: Elaboração própria.

Observamos também que falar sobre os processos psicológicos das crianças em torno/sobre os textos e falar sobre os textos em si foram as categorias que concentraram o maior número de referências por parte das professoras. Em relação à fala sobre os processos psicológicos, predominou a formulação de perguntas às crianças sobre seus processos cognitivos - o que acreditam, pensam, sabem, lembram, etc. - em relação ao texto. Em menor medida, as professoras fizeram afirmações ou declarações sobre esses mesmos processos (ver Tabela 3). Quanto à análise do conteúdo de tais perguntas e afirmações (ver Tabela 3), predominaram a indagação (o que vocês acham/imaginam que vai acontecer?) e as referências (vocês pensam/acreditam que o lobo vai comer os cabritinhos:) às crenças dos alunos. Em menor medida, apareceram indagações e referências aos conhecimentos (saber/lembrar) e, finalmente, às reações emotivas (gostar).

TABELA 3 - Análise da fala sobre os processos psicológicos dos alunos

\begin{tabular}{lcccc}
\hline \multirow{2}{*}{ Categorias de análise } & \multicolumn{3}{c}{ Número total de enunciados por código } \\
\cline { 2 - 5 } & MT-D & MT-I & SP-D & SP-I \\
\hline $\begin{array}{l}\text { Modo da fala sobre os processos } \\
\text { psicológicos dos alunos }\end{array}$ & & & & \\
$\quad$ Perguntas & 4 & 31 & 19 & 46 \\
$\quad$ Afirmações & 2 & 12 & 4 & 15 \\
Conteúdo da fala sobre os processos & & & & \\
psicológicos dos alunos & 1 & 21 & 11 & 30 \\
$\quad$ Perguntas sobre crenças & & 8 & 1 & 7 \\
$\quad$ Perguntas sobre conhecimentos & 3 & 4 & 7 & 14 \\
$\quad$ Perguntas sobre emoções & 2 & 2 & 3 & 7 \\
Afirmaç̃os sobre crenças & & 6 & 1 & 2 \\
Afirmações sobre conhecimentos & & 2 & & 1 \\
$\quad$ Afirmaç̃óes sobre emoções & & & & \\
\hline
\end{tabular}

Fonte: Elaboração própria. 
A análise apresentada na Tabela 4 mostra que, de um modo geral, quando as professoras falaram dos textos, fizeram predominantemente comentários metatextuais, isto é, focaram aspectos do texto e, também, mas em menor medida, comentários referenciais. As professoras de perfil diretivo/transmissivo coincidiram ao realizarem quase a mesma proporção de comentários referenciais e de comentários metatextuais. A professora MT-D se diferenciou da professora SP-D por realizar algumas paráfrases do texto lido e comentários interpretativos. É importante notar que estes últimos, segundo nosso sistema de categorias (definido na seção Dados e análises), são enunciados nos quais a professora tenta transmitir de forma direta uma determinada interpretação do texto (a dela) e, nesse sentido, são comentários que revelam um perfil mais diretivo e transmissivo.

No caso das professoras de perfil interativo/construtivo, a análise revelou importantes diferenças. A professora MT-I realizou muitas vezes comentários referenciais e interpretativos, ao contrário da professora SP-I, que focou sua fala em aspectos específicos do texto (comentários metatextuais), quadriplicando em número os enunciados da professora do Mato Grosso na mesma categoria. Esses resultados demonstram que a professora MT-I, comparada com SP-I, ainda que identificada como tendo um perfil mais construtivo, é, em certo sentido, transmissiva. Ao contrário, a professora SP-I (em comparação com as demais participantes) destaca-se pela intensa referência ao próprio texto.

O predomínio de comentários metatextuais levou-nos a indagar qual seria o seu conteúdo - o que as professoras disseram sobre os textos? Ainda na Tabela 4, expomos os resultados da análise de conteúdo desse subconjunto específico de dados. Observamos que, na maioria das vezes, foram referências aos acontecimentos ou eventos narrados na história; essa referência foi seguida, apenas no caso das professoras de São Paulo, da fala sobre a relação do texto lido com outros textos (intertextualidade). Em menor medida, encontramos referências aos personagens da história e, quase que com ocorrências únicas, as informações relativas ao título e ao autor do texto, ao tema ou assunto da história (MT-D; SP-I), ao tipo de texto (MT-D), ao final da história (SP-I) e ao vocabulário (MT-I). 
TABELA 4 - Análise do subconjunto de dados categorizado como fala sobre textos

\begin{tabular}{lllll}
\hline \multirow{2}{*}{ Categorias de análise } & \multicolumn{4}{c}{ Número total de ocorrências por código } \\
\cline { 2 - 5 } & MT-D & MT-I & SP-D & SP-I \\
\hline Tipo de fala sobre o texto & 3 & 24 & 4 & 6 \\
$\quad$ Comentário referencial & 2 & 14 & & 4 \\
Comentário interpretativo & 3 & 9 & & 2 \\
Paráfrases do texto & 12 & 19 & 13 & 84 \\
Comentário metatextual & & & & \\
Conteúdo dos comentários metatextuais & 1 & 5 & 1 & \\
Nome do texto & 1 & & 1 & 3 \\
Autor do texto & & 1 & & 1 \\
Tema do texto & 2 & & & \\
Tipo de texto & 2 & 2 & & 12 \\
Personagens & 6 & 8 & 6 & 52 \\
Acontecimentos & & & & 2 \\
Final da história & & & & \\
Vocabulário & & & & \\
Relação com outros textos & & & & \\
\hline
\end{tabular}

Fonte: Elaboração própria.

Dentre os resultados destacamos dois tipos de diferenças: as observadas na subcategoria acontecimentos e na subcategoria relação com outros textos. Em relação à primeira subcategoria, registramos que a professora SP-I realizou um trabalho de referência aos acontecimentos da história muito mais denso do que suas colegas.

O estudo do subconjunto de dados comentários metatextuais referidos aos acontecimentos mostrou que, em quase todos os casos, tratou-se de perguntas e, em menor medida, afirmações (ver Tabela 5). No caso da professora MT-I, houve mais afirmações sobre os acontecimentos do que perguntas. Destacamos também a quantidade de perguntas formuladas pela professora de perfil interativo/ construtivo de São Paulo (mais que o dobro, se comparada com a quantidade de afirmações). Em relação à variedade de questões, a Tabela 5 mostra que a professora de perfil interativo/construtivo de São Paulo se diferenciou de forma significativa das demais. As 
professoras do Mato Grosso e a professora de perfil diretivo/ transmissivo de São Paulo (SP-D) fizeram, em maior medida, perguntas fechadas (que levam a afirmar ou negar informações dadas sobre os eventos) enquanto a professora interativa/construtiva de São Paulo utilizou uma ampla variedade de questões.

TABELA 5 - Análise do subconjunto de dados categorizados como comentários metatextuais referidos aos acontecimentos da história

\begin{tabular}{|c|c|c|c|c|}
\hline \multirow{2}{*}{ Categorias de análise } & \multicolumn{4}{|c|}{ Número total de ocorrências por código } \\
\hline & MT-D & MT-I & SP-D & SP-I \\
\hline \multicolumn{5}{|l|}{ Tipo de comentários metatextuais } \\
\hline \multicolumn{5}{|l|}{ sobre acontecimentos } \\
\hline Afirmações sobre acontecimentos & & 6 & 3 & 14 \\
\hline Perguntas sobre acontecimentos & 6 & 2 & 3 & 38 \\
\hline \multicolumn{5}{|l|}{ Tipo de perguntas sobre acontecimentos } \\
\hline 0 que? & 2 & & & 14 \\
\hline Para quê? & 1 & & & 4 \\
\hline Por quê? & & & & 6 \\
\hline Como foi? & & & 1 & 3 \\
\hline Onde? & & & & 1 \\
\hline Quem? & & & & 1 \\
\hline Pergunta fechada & 3 & 2 & 2 & 9 \\
\hline
\end{tabular}

Fonte: Elaboração própria.

\section{Verbos metacognitivos e metalinguísticos}

A medida da quantidade e do tipo de verbos que dizem respeito explicitamente às ações cognitivas e linguísticas mostra, novamente, que há maior densidade desses verbos no discurso das professoras de perfil interativo/construtivo. Nesse sentido, trata-se de um indicador que diferencia os perfis. Na Tabela 6, sobressai a quantidade e variedade de verbos empregados por parte da professora de perfil interativo de São Paulo. 
TABELA 6 - Densidade e diversidade de verbos metalinguísticos e metacognitivos

\begin{tabular}{lllll}
\hline \multirow{3}{*}{ Categorias de análise } & \multicolumn{4}{c}{ Número total de ocorrências por código } \\
\cline { 2 - 5 } & MT-D & MT-I & SP-D & SP-I \\
\hline
\end{tabular}

Densidade de verbos metacognitivos

e metalinguísticos

Verbos metacognitivos

Verbos metalinguísticos

Diversidade de verbos metalinguísticos

Ler

Dizer

Reconstruir

Conversar

Falar

Contar

Apresentar

Perguntar
6

1

1

5

1

1

12

48

20

$\begin{array}{lll}7 & 9 & 20\end{array}$

$\begin{array}{ll}4 & 4 \\ & 1 \\ 3 & 1 \\ 2 & 9 \\ & 3 \\ & 1 \\ & \end{array}$

Diversidade de verbos metacognitivos

$\begin{array}{ll}\text { Achar } & 1 \\ \text { Concordar } & 1 \\ \text { Descobrir } & 3 \\ \text { Ver } & 1 \\ \text { Adivinhar } & \\ \text { Atender } & \\ \text { Concluir } & \\ \text { Entender } & \\ \text { Gostar } & \\ \text { Ouvir } & \\ \text { Pensar } & \\ \text { Saber } \\ \text { Conhecer } \\ \text { Imaginar } \\ \text { Interpretar } \\ \text { Lembrar } \\ \text { Olhar } \\ \text { Reparar } \\ \text { Acertar } \\ \text { Escutar } \\ \text { Esquecer } \\ \text { Perceber }\end{array}$




\section{Discussão e conclusões}

Nesta pesquisa, nos perguntamos em que medida professoras de diferentes perfis pedagógicos se apropriariam de uma série de orientações sobre os modos de apresentar e conduzir verbalmente atividades de leitura e comentário de texto. Também perguntamos pelo modo em que variaria a qualidade mais ou menos letrada do seu discurso educativo em função de seu perfil.

No que diz respeito à primeira pergunta, os resultados mostraram que o acompanhamento das orientações dos materiais educativos diferenciou as professoras por perfil no estado do Mato Grosso, mas não no estado de São Paulo. A professora de perfil diretivo/transmissivo do Mato Grosso não incorporou nenhum dos exemplos relativos ao discurso educativo e a professora de perfil interativo/construtivo se apropriou de alguns. No caso das professoras do estado de São Paulo, as duas acompanharam fielmente o roteiro de trabalho proposto, incorporando os exemplos sobre o discurso educativo, mais fielmente a professora de perfil diretivo/transmissivo do que a de perfil interativo/construtivo. No entanto, levando em consideração o total de análises realizadas, essa apropriação do roteiro não fez com que sua prática de ensino fosse igual ou mais letrada do que a da professora de perfil interativo/construtivo, o que revela quão determinante é o perfil comunicativo/pedagógico do professor.

No que diz respeito à segunda pergunta, as análises realizadas mostraram que a qualidade letrada do discurso educativo das professoras durante a atividade de leitura e comentário de um livro de literatura infantil variou significativamente em função do seu perfil comunicativo/pedagógico. Assim, observamos que, em comparação com suas colegas de perfil diretivo/transmissivo, as professoras de perfil interativo/construtivo:

- fizeram um maior número de referências no discurso às atividades de ensino e aprendizagem desenvolvidas em torno do texto, aos processos psicológicos dos alunos e ao texto propriamente dito;

- formularam mais perguntas. As professoras interativas/ construtivas optaram em maior medida pelo modo enunciativo interrogativo, propiciando diálogos e estimulando os alunos a dizerem o que pensavam e conheciam do texto. Esse dado é coerente com um perfil que, por princípio, opta pelo trabalho ativo, e não receptivo, do aluno no processo de ensino e aprendizagem; 
- empregaram com maior frequência a variedade de verbos metacognitivos e metalinguísticos para nomear as atividades psicológicas dos alunos em torno dos textos; e

- dedicaram um tempo maior para desenvolver as atividades propostas.

Esses resultados são coerentes com estudos prévios sobre o caráter letrado próprio da fala sobre textos (ASTINGTON, 1998; ASTINGTON; OLSON, 1990; WATSON, 2002; SEPÚLVEDA, 2012) e também com os achados das pesquisas sobre as características do discurso educativo associadas a práticas de ensino e aprendizagem exitosas e de caráter construtivo (MERCER, 2000, 2003; WEGERIF; MERCER; ROJAS-DRUMMOND, 1999).

\section{CONSIDERAC̣ÕES FINAIS}

O presente estudo é somado a um trabalho piloto prévio (SEPÚLVEDA, 2012) com o objetivo de configurar um sistema de análise da qualidade letrada das práticas de leitura e comentário de livros de literatura infantil em sala de aula. Ainda que os dois estudos tenham sido trabalhos em pequena escala, permitiram-nos elaborar um sistema que resultou sensível às diferenças. Como mostram os resultados desta pesquisa, as categorias de análise conseguem caracterizar dissemelhanças importantes na qualidade da prática educativa estudada.

Em relação às limitações do estudo e, ao mesmo tempo, dos desafios para pesquisas futuras do ponto de vista metodológico, temos de validar o sistema de análise com um corpus maior de dados. Como se discutiu na seção de fiabilidade, é necessário seguir conferindo a estabilidade de alguns dos elementos do sistema de análise e refinar, se for o caso, a definição de algumas categorias.

Por outra parte, do ponto de vista educativo, consideramos que, em conjunto, os resultados nos estimulam a seguir estudando o potencial que têm os exemplos dos modos de fazer-dizer na contínua formação de professores alfabetizadores. Em futuras pesquisas, isso poderia exigir optar por desenhos de intervenção mais extensos e intensivos, nos quais possam ser utilizadas técnicas formativas de comprovada eficácia (DAMHUIS; DE BLAUW, 2008), como a visualização e a análise com a professora de sequências de vídeos realizadas em sua aula.

\section{REFERÊNCIAS}

ASTINGTON, J. Theory of mind goes to school. Educational leadership, Alexandria, v. 56, n. 3, p. 46-48, Nov. 1998. 
ASTINGTON, J.; OLSON, D. Metacognitive and metalinguistic language: learning to talk about thought. Applied Psychology: An International Review, v. 39, n. 1, p. 77-87, 1990.

ATLAS.TI SCIENTIFIC SOFTWARE DEVELOPMENT GMBH. ATLAS.ti [Programa informático], Berlin, 2002-2011.

BALLESTEROS, X.; RODRÍGUEZ, S.; MÍGUEZ, A. Os sete cabritinhos. São Paulo: Callis, 2009.

BRANDAO, A.C.; LEAL, T.F.; NASCIMENTO, B. E. Conversando sobre textos na alfabetização: o papel da mediação docente. Cad. CEDES, Campinas, v. 33, n. 90, p. 215-236, 2013. Disponível em: < http://www.scielo.br/scielo.php?script=sci_arttext\&pid=S0101-32622013000200004\&ln $\mathrm{g}=$ en\&tlng=pt. 10.1590/S0101-32622013000200004> . Acesso em: 28 ago. 2014.

BRASIL. MINISTÉRIO DE EDUCAÇÃO. Trilhas. São Paulo, SP: Ministério de Educação, 2011. BRUNER, J. Realidad mental y mundos posibles. Barcelona: Gedisa, 1997.

BUS, A.G.; VAN IJZENDOORN, M.H. Mother-child interactions, attachment, and emergent literacy: A cross-sectional study. Child Development, Ann Arbor, 59, p. $1262-$ 1273, 1988 .

BUS, A.G.; VAN IJZENDOORN, M.H.; PELLEGRINI, A. Joint book reading makes for success in learning to read: A meta-analysis on intergenerational transmission of literacy. Review of Educational Research, Washington, v. 65, n. 1, p. 1-21, 1995.

COLL, $\mathrm{C}$ et al. Actividad conjunta y habla: una aproximación al estudio de los mecanismos de influencia educativa. In: BERROCAL, P. F.; MELERO, M. (Ed.). La interacción social en contextos educativos. Madrid: Siglo XXI, 1995. p. 194-326.

COLOMER, T. Andar entre libros: la lectura literaria en la escuela. México: Fondo de Cultura Económica, 2005.

DAHL, K.; FREPPON, P. A comparison of innercity children's interpretations of reading and writing instruction in the early grades in skills-based and whole language classrooms. Reading Research Quarterly, v. 30, n. 1, p. 50-74, 1995.

DAMHUIS, R.; DE BLAUW, A. High quality interaction in the classroom. A focus for professional learning. L1 Educational Studies in Language and Literature, v. 8, n. 4, p. 107-126, 2008.

DOMBEY, H. Interactions between Teachers, Children and Texts in Three Primary Classrooms in England. Journal of Early Childhood Literacy, v. 3, n. 1, p. 37-58, 2003.

FISHER, C.; HIEBERT, E. Characteristics of tasks in two approaches to literacy instruction. The Elementary School Journal, v. 91, n. 1, p. 3-18, 1990.

HEATH, B. Ways with words. Language, life, and work in communities and classrooms. Cambridge: Cambridge University Press, 1983.

JOHN, C. Reading lessons: teacher-pupil interactions with text during three KS1 shared reading sessions. Literacy, v. 43, n. 3, p. 123-133, 2009.

LANCIA, P. Literary borrowing: The effects of literature on children's writing. The Reading Teacher, v. 50, n. 6, p. 470-475, 1997.

MARTLEW, J. et al. Teacher and child talk in active learning and whole-class contexts: some implications for children from economically less advantaged home backgrounds. Literacy, v. 44 , n. 1 , p. 12-19, 2010.

MERCER, N. Palabras y mentes. Cómo usamos el lenguaje para pensar juntos. Barcelona: Paidós, 2000. 
MERCER, N. Helping children to talk and think together more effectively. Polifonia, 7, p. 1-26, 2003.

MORROW, L. M.; GAMBRELL, L. Literature-based reading instruction. In: M. KAMIL, et al. (Eds.), Handbook of reading research. New Jersey: Lawrence Erlbaum Associates, 2000. p. 563-586.

MORROW, L. M. Literacy development in the early years. Needhan Heights, MA: Ally \& Bacon, 1997.

OLSON, D. El mundo sobre el papel. Barcelona: Gedisa, 1994.

OLSON, D.; ASTINGTON, J. Talking about text: how literacy contributes to thought. Journal of Pragmatics, 14, p. 705-721, 1990.

PAPPAS, C.; VARELAS, M. Multimodal books in science-literacy units: Language and visual images for meaning making. Language Arts, v. 86, n. 3, p. 201- 211, 2009.

PAQUETTE, K. R. Encouraging primary students' writing through children's literature. Early Childhood Education Journal, v. 35, n. 2, p. 155-165, 2007.

PHILLIPS, L. M. Using children's literature to foster written language development. St. John's, Newfoundland: Institute for Educational Research and Development, Memorial University of Newfoundland, Canada. (ERIC Document Reproduction Service $\mathrm{N}^{\circ}$ ED276027), 1986.

PRESSLEY, M. et al. A study of effective first-grade literacy instruction. Scientific Studies of Reading, v. 5, n. 1, p. 35-58, 2001.

SÉNÉCHAL, M., CORNELL, E. H.; BRODA, L. Age-related changes in the organization of parent-infant interactions during picture-book reading. Early Childhood Research Quarterly, 10, p. 317-337, 1995.

SÉNÉCHAL, M. The differential effect of storybook reading on preschoolers' acquisition of expressive and receptive vocabulary. Journal of Child Language, 24, p. 123-138, 1997.

SÉNECHAL, M.; LEFEVRE, J.A. Parental Involvement in the Development of Children's Reading Skill: A Five-Year Longitudinal Study. Child Development, v. 73, n. 2, p. 445- 460, 2002. SEPÚLVEDA, A. Incorporação de práticas letradas na alfabetização. Cadernos Cenpec: Nova Série, v. 2, n. 2, 189-223, 2012. Disponível em: <http://cadernos.cenpec.org.br/ cadernos/index.php/cadernos/article/view/184/212>. Acesso em: 10 Out. 2013.

SNOW, C. Literacy and language: relationships during the preschool years. Harvard Educational Review, 53, p. 165-189, 1983.

SNOW, C.; GOLDFIELD, B. A. Turn the page, please: situation specific language acquisition. Journal of child language, 10, p. 535-549, 1983.

SNOW, C.; NINIO, A. The contracts of literacy: what children learn from learning to read books. In: W. TEALE; E. SULZBY (Eds.). Emergent literacy: Writing and reading. Norwood, NJ.: Ablex Publishing Corporation, 1986.

SNOW, C., BURNS, M.; GRIFFIN, P. Preventing reading difficulties in young children. Washington D.C.: National Academy Press, 1998.

TEALE, W.H.; SULZBY, E. Emergent literacy: A perspective for examining how young children become writers and readers. In: W.H. TEALE; E. SULZBY, (Eds.), Emergent literacy: Writing and reading. Norwood, NJ: Ablex Publishing Corporation, 1986.

TEBEROSKY, A. Aprendiendo a escribir. Barcelona: Horsori, 1993.

TEBEROSKY, A. Proposta constructivista per aprendre a llegir i a escriure. Barcelona: Vicens Vives, 2001. 
TEBEROSKY, A. Desde la literatura al aprendizaje del lenguaje y su escritura. In: SIMPOSIO INTERNACIONAL LA LITERATURA QUE ACOGE: INFANCIA, INMIGRACIÓN Y LECTURA, 2011, Barcelona. Actas... Barcelona: Universitat de Barcelona. Disponível em: http://www.aprendretextos.com/. Acesso em: 1 jun. 2012.

TEBEROSKY, A et al. El discurs sobre els textos i el coneixement textual. Articles: Revista de didàctica de la llengua i de la literatura, 40, p. 50-65, 2006.

TORRANCE, N.; OLSON, D. Development of the metalanguage and the acquisition of literacy: a progress report. Interchange, v. 18, n. 1/2, p. 136-146, 1987.

WATSON, R. Literate discourse and cognitive organization: Some relations between parents' talk and 3-year-olds' thought. Applied Psycholinguistics, 10, p. 221-236, 1989.

WATSON, R. Talk about text: literate discourse and metaliterate knowledge. In: REEDER, K. et al. (Ed.). Literate apprenticeships: the emergence of language and literacy in the preschool years. New Jersey: Ablex Publishing, 1996. p. 81-100.

WATSON, R. Literacy and oral language: implications for early literacy acquisition. In: NEUMAN, S. B.; DICKINSON, D.K. (Eds.). Handbook of Early Literacy Research. New York: The Guilford Press, 2002. p. 43-65.

WELLS, C. G. Language development in the pre-school years. Cambridge: Cambridge University Press, 1985.

WEGERIF, R; MERCER, N.; ROJAS-DRUMMOND, S. Language for the social construction of knowledge: comparing classroom talk in Mexican. Language and education, v. 12, n. 2, p. 133-150, 1999.

\section{NOTAS}

${ }^{1}$ Para a realização do procedimento de avaliação interobservadores, a autora do artigo contou com a colaboração de Professora Doutora Otília Sousa, da Escola Superior de Educação de Lisboa.

Submetido: 01/10/2014

Aprovado: 31/08/2016

Contato:

Luz Angélica Sepúlveda Castillo

Rua Artemio Zonta, 61, Bairro Noga - Castanheira

Mato Grosso|MT|Brasil

CEP 78.345-000 



\section{ANEXO A - INSTRUMENTO PARA CARACTERIZAR O PERFIL E AS PRÁTICAS DE ALFABETIZAÇÃO DAS PARTICIPANTES}

Perspectiva de ensino e aprendizagem

Ensino transmissivo, preocupado em oferecer aos alunos conceitos e regras prontas para que eles memorizem.

Perspectiva centrada em automatismos e reproduções mecânicas.

Desatenção das opiniões, iniciativas, perguntas... do ponto de vista dos alunos.

Alta dependência do professor na resolução de atividades e tarefas.

0 trabalho na sala se organiza em torno da inter-relação entre as atividades de ler, escrever e falar sobre 0 lido e 0 escrito.

Privilegia a reflexão dos alunos sobre as diferentes possibilidades de emprego da língua.

Os intercâmbios comunicativos na sala de aula estão centrados na construção de significado (na negociação de significado com os alunos) com atenção às perguntas, iniciativas, perspectivas dos alunos.

Promoção da autorregulação e autonomia (o professor mostra explicitamente aos alunos como se autorregular).

Promoção da reflexão dos alunos sobre seu próprio trabalho.

Os alunos dedicam um maior tempo a desenvolver atividades academicamente demandantes das que não 0 são (exemplo: mais tempo escrevendo do que colorindo desenhos prontos).

\section{Materiais educativos e ambiente físico da sala de aula}

Uso de cartilhas, silabários, materiais centrados na progressão de unidades menores a unidades maiores (letras, sílabas, palavras, frases, textos).

Na sala de aula há cartazes com silabários.

Nos cadernos há produções que correspondem às tarefas de cópia, ditado, traçado de letras, repetição de sílabas, palavras etc.

Não usa o livro didático.

Uso de livros e textos para o ensino (materiais autênticos).

Na sala de aula há livros e diversos materiais textuais disponíveis.

Na sala de aula há um local de exposição permanente das produções escritas dos alunos (de diversos tipos).

Na sala de aula há cartazes com listas de palavras (identificar critério da lista). 
Práticas de ensino e aprendizagem

Instrução sistemática e explícita das correspondências grafema-fonema.

Orientação à leitura correta e rápida de sílabas e palavras.

Controle individual da leitura em voz alta (tomada de leitura).

Ditado de sílabas (palavras, frases, textos) aos alunos.

Cópia de letras, sílabas, palavras, frases, textos no caderno.

Tarefas individuais de discriminação de grafemas.

As produções infantis são corrigidas sem consideração da estratégia de produção, somente na perspectiva da convenção ortográfica.

Um número significativo de crianças não realiza atividades produtivas de aprendizagem, durante $90 \%$ do tempo.

0 professor reflete com os alunos sobre suas estratégias de produção escrita.

Leitura compartilhada de histórias.

Estimulação da compreensão de leitura antes, durante e após a leitura do texto.

São aproveitadas diversas ocasiões para o ensino explícito de vocabulário.

Releitura de histórias conhecidas.

É reconhecível um propósito da leitura evidente nos comentários que o professor estimula antes, durantes e após a leitura.

Dedica-se tempo à leitura independente.

Estimulação do reconto oral infantil das histórias lidas.

Conversações sobre livros e textos escritos.

Análise de palavras escritas.

Jogos de linguagem (reflexão sobre sua estrutura).

Escrita coletiva de textos com base nos textos lidos.

Escrita individual de textos com base nos textos lidos.

Leitura coletiva de textos.

Ditado ao professor.

O professor escreve palavras com erros (ortográficos) para promover a análise coletiva.

Análise e reflexão (coletiva) das produções infantis.

A maioria das crianças $(90 \%)$ desenvolve atividades produtivas de oralidade, leitura e escrita, durante a maior parte do tempo $(90 \%)$.

Nota: em cor cinza destacamos as linhas referentes a comportamentos que podem caracterizar o perfil diretivo/ transmissivo e em branco os comportamentos correspondentes ao perfil interativo/construtivo. A prevalência de uns sobre outros nos ajudou a identificar o perfil das professoras.

Fonte: Elaboração própria. 
ANEXO B - EXEMPLO DA ESTRUTURA DAS ATIVIDADES PROPOSTAS AO PROFESSOR NO CADERNO DE ORIENTAÇÕES: HISTÓRIAS COM ENGANO
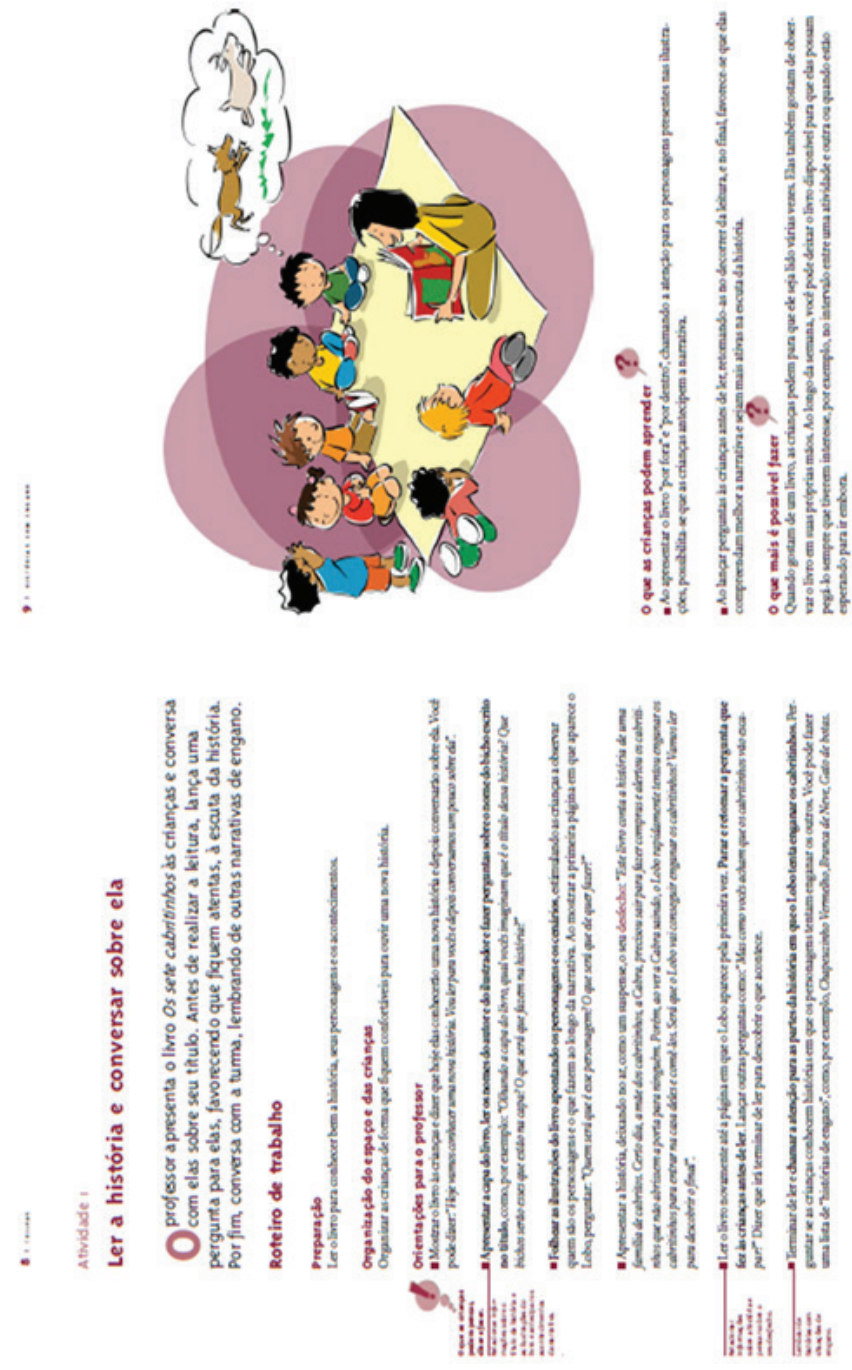
